\title{
Generic Competencies in the Education of Engineers: The Case of Engineering Program in a Public University in Mexico
}

\author{
Alejandra García Serna ${ }^{1}$, José Luis Arcos Vega ${ }^{2}$, Juan José Sevilla García ${ }^{1}$ \& María Amparo Oliveros Ruiz ${ }^{3}$ \\ ${ }^{1}$ Instituto de Ingeniería, Universidad Autónoma de Baja California, Mexicali, Mexico \\ ${ }^{2}$ Universidad Politécnica de Baja California, Mexicali, Mexico \\ ${ }^{3}$ Facultad de Pedagogía e Innovación Educativa, Universidad Autónoma de Baja California, Mexicali, Mexico \\ Correspondence: Juan J. Sevilla-García, Engineering Institute, Universidad Autónoma de Baja California, Baja \\ California, México. Tel: 1-686-566-4150. E-mail: jsevilla@uabc.edu.mx
}

Received: November 23, $2017 \quad$ Accepted: December 15, $2017 \quad$ Online Published: February 8, 2017

doi:10.5539/hes.v8n1p58

URL: https://doi.org/10.5539/hes.v8n1p58

\begin{abstract}
We present an analysis regarding generic skills on engineering program offered in a public state university in Mexico (UABC). The university implemented a new educational model changing rigid programs to flexible programs based on competencies. The goal is to determine generic skills related to the four pillars of learning: learning to do, learning to know, learning to be, and learning to live together. This work is non experimental, cross-sectional, and descriptive. The study reflect upon the generic competences that students consider are being promoted during their first years in the university and provides a reference for the methodology to identify development of generic skills in engineering students.
\end{abstract}

Keywords: generic skills, higher education, engineering students, competencies, public university

\section{Introduction}

Higher education institutions in Mexico (IES) have the mission of produce knowledge and culture and to collaborate in the construction of a more fair and balanced society as well as improve life quality of its graduates (Asociación Nacional de Universidades e Instituciones de Educación Superior [ANUIES], 2006). The Engineering Academy (AI) defines, among the obstacles for the advancement of engineering in Mexico, the lack of promotion of values and inter and intrapersonal abilities in engineering students (Academia de Ingeniería [AI], 2007). Facing these challenges, some higher education institutions in Mexico have worked these last years in the implementation and consolidation of Education Models Based on Abilities to respond with excellence to the demands in their surroundings. Regarding higher education, the competence process requires the interaction of teaching and learning activities that develop knowledge, attitudes, abilities, skills, and ethic sense in students. Some IES have sustained this process in the four education pillars pointed out by UNESCO: Learning how to know, Learning how to do, Learning how to live together, and Learning how to be; this are considered the pillars of knowledge and learning throughout life, for they have as objective to provide the instruments to stimulate the people's critical sense, future learning, and to influence their own contexts (Delors, 1996). Due to the many components and elements related to the concept of competence, it is complex to establish the dimensions for its learning, teaching, and evaluation. This work identifies the generic competences that are developed in higher education students after finishing the first training part of an engineering program in the Autonomous University of Baja California (UABC), a public institution located in the northeastern region of Mexico, which has made the transition into curricular adjusting in 2003, and implemented a course of study based in competences under an holistic approach that covers knowledge, attitudes, aptitudes, abilities, skills, and values in 2006.

Organizations as UNESCO and ANUIES establish that the formation of high level human resources is needed for the transition into knowledge societies and for a socially sustainable economic growth. Regarding countries with growing economies such as Mexico, having employed university graduates formed by an integral approach of higher education allows the generation of quality jobs (ANUIES, 2006; UNESCO, 2017. Likewise, having a more qualified workforce can positively influence the development of science and technology based on knowledge and innovation (Etzkowitz \& Leydesdorff, 2000; Gordillo \& Osorio, 2003). According to previously reported research related to the development of competencies, a problem was identified: not all interpersonal and 
linguistic abilities have been developed in the same grade as the technical capacities during the professional training in different knowledge fields. Due to the important participation of the UABC in the training of engineers in the State, the training of generic competences in engineering students is an important task for the integral training of university students (UABC, 2015).

In terms of the relevance of the study of interpersonal abilities required for professionals in science, technology, engineering, and mathematics areas, Vázquez-Alonso \& Manassero-Mas (2013) point out: the positive attitude, to express feelings in a constructive way, respect, tolerance, to identify the impact of their decisions with their surroundings, critical thinking, inquiry and search, observation, classification, interpretation, comparison, prediction, identification of problem causes, and the suggestion of solutions to problems. Another important area where generic competences are required is the labor area, Fernández, Gutiérrez \& Hilera made a study in 2010 in order to identify the abilities requested in job offers between 2002 and 2005. They found that these abilities are required in $31.35 \%$ of the cases with vacancies offered, showing an increase of $34.3 \%$ in 2007 . While in the time between 2008 and 2009, these skills where included in 47.3\% of the job descriptions. With regard to high-tech companies, a study endorsed by the Consultant Commission of High Technology of Costa Rica (CAATEC) revealed that there are gaps in human resources required by Multinational High Technology Companies (EMATs) located in Costa Rica, referring to both their academic grades and their competences, mainly identifying the skills in problem solving, sciences, and mathematics, business management, and the knowledge of foreign languages (Torres \& González, 2002). During the last years Ginés (2003) has carried out several follow-up studies of university graduates in Europe. In his findings regarding the working status of higher education Young graduates in Europe, in 2003 Spanish students consider that their preparation is acceptable and generally show satisfaction in their studies and work. Nonetheless, the study also revealed that university graduates have a deficiency in professional competences, especially in those of social and participatory nature.

Among the contributions of some authors in Mexico, is the study carried out on 2012 by Medina, Casillas, \& Zayas, it was concluded that the six generic competences that are requested the most by employers in different zones of the Mexican Republic are the capacity of teamwork, the capacity to identify, plan, and solve problems, the capacity to apply knowledge, the commitment to quality, the capacity of decision making, and the capacity to organize and plan time. Another case is the one presented by González \& Hernández (2014) in which they concluded that $60 \%$ to $65 \%$ of students proceeding from public institutions have a deficient or medium performance in linguistic abilities such as the capacity to understand and interpret that which I heard; the capacity to transform linguistic signs into mental images and the appropriate use of language. In that same regard Guerra, et al., (2014) found that school activities do not promote the interest of reading among university students. An important contribution was made by Amieva in 2001, where it was established that most of the laboratory, research, or technical reports made by engineering students have deficiencies regarding written communicational competences such as: scarce data interpretation or analysis, lack of conclusions, and confusion between results and conclusions. In their study, made at a State Public University, Galaz \& Sevilla (2007) concluded that $54 \%$ of bachelor's degree students stated that they agree or totally agree that there is a social and community commitment from the university, while the rest stated a neutral opinion or disagree to it. Regarding their opinion about the promoting of university values, $62.8 \%$ of students stated they share the university's values, 29\% stated a neutral opinion, and $8.2 \%$ stated they disagree. On the other side, Oliveros, Sevilla \& Shor (2010) suggest, in their study, the need to promote the impact of values in the development of a society and to motivate in students the interest to learn about science and technology. The generic competences in the UABC have been defined according to the contributions of De Asis (2007) \& Bellocchio (2010), where they are established as those that allow the training of subjects so they can perform appropriately in the work field and for their development in life. These competences correspond to the abilities that the student must develop in a certain training process and are not related to a particular discipline or profession. The definition of the four education pillars in the UABC has been established based on the contributions of many authors. Learning how to know is measured by the following capacities and abilities: thinking, discovering, constructing and reconstructing knowledge. It involves curiosity, autonomy, attention, memory and thinking, knowledge of specialized content, interest for reading, acquisition of languages, thought abilities, critical sense, autonomy, management of digital tools in order to search information, and interest for research, among others. Learning how to do refers to the development of the following capacities and abilities: social behavior, teamwork, initiative, assuming risks, work collectively, intuition, emotional stability, effective communication, and conflicts solving (Sáez, 2006; Perrenoud, 2006; Delors, 1996; Gadotti, 2003). Regarding the pillar learning how to live together, UABC establishes that it corresponds to the capacity of subjects to live in diversity and equality, the search of the ideas coincidence spots, the comprehension towards other people, the acceptance of interdependence among human beings, the respect to pluralism, mutual comprehension, appreciation of peace, 
empathy, participation in cooperative projects, and participation in social activities (UABC, 2013). Learning how to be is defined as the capacity of students to be sensitive, the management of ethics and esthetics, social and personal responsibility, spirituality, autonomous and critical thinking, imagination, creativity and initiative, and the knowledge of being a citizen of the world (Delors, 1996). Based on the analysis of the authors that have studied this subject, this research had as objectives to know the generic competences developed by engineering students that have studied through the first phase of the training process under the current Course of Study 2009-2 in UABC, and to contribute a methodology example for the future valuation of generic competences in engineering students.

\section{Method}

We used a quantitative and descriptive methodology according to Hernández, Fernández, Baptista \& Collado (2003). We made a transverse study by considering a specific school term. The methodology consisted in the review of records of the study subject, the problem's setting, the definition of objectives, integration of the theoretical framework, definition of variables, the verification of coherence between the question and research objectives, the identification of population and study sample, design and measurement instruments validation, data collection, data codification, data analysis, results presentation, discussion, and conclusion. For the validation of the instrument, we verified the document's internal consistency, applying the measurement for the calculation of the Cronbach coefficient; using the reliability test of the scale using SPSS The results of the test were interpreted according to the following consideration: 0.25 low reliability, 0.50 medium reliability, 0.75 or superior, acceptable; 0.90 high, in order to for it to be considered seriously. The result obtained in the reliability test for a total of 18 questions was of 0.907 . We applied the split-half method. On the first half an alpha Cronbach coefficient of 0.834 was obtained and a 0.848 coefficient on the second half, which guarantees the reliability of the instrument used. The information was collected through an opinion survey applied to students that finished the phase of basic training under the current Course of Study at UABC. A total of 1376 students are attended in the basic stage in the study cycle. The survey consisted of 18 questions pertaining to the 4 study dimensions: (learning how to know, learning how to do, learning how to be, and learning how to live together) in order to valuate eighteen study variables (Beneitone, 2007). Many questions in relation to each variable were generated (Corbetta, 2007; Hernández and others, 2003; Rojas, 1998; Tamayo, 1994). The application of opinion surveys to students was of self-administered context in order to provide a better anonymity guarantee for all participants in the survey process. A probabilistic sample of students was selected and 324 questionnaires were applied. The degree of confidence of $95 \%$ and maximum error of the estimate of $5 \%$ were selected. Based on the lack of existence of an estimate of "p" obtained from previous samples, the value of 0.5 has been assigned as much as for "p" as for "q", under the justification that the highest possible value of "p.q" is 0.25 , which is true when $\mathrm{p}=0.5$ and $\mathrm{q}=0.5$; which ensures that the sample size will be of the size required to ensure reliability (Triola, 2000).

\section{Results}

For the descriptive analysis of data, we used the SPSS program. It should be considered that the results presented in this study reflect the opinion of students for a particular school term and specific training process, such as the basic training phase of engineering programs. Nonetheless, these results constitute an example that allows to reflect upon the generic competences that students consider are being promoted during their first years in the university. The questions in the survey were formed by affirmations regarding the promotion of generic competences during the courses taken through the basic phase for all engineering programs. These percentages showed have been calculated while taking into account all the answers obtained where the people surveyed stated that they disagree or partially agree to the affirmations presented. The opinion of 324 surveyed students is presented. In order to systematize qualitative description of results, we chose the following convention to distinguish the percentages obtained: 0 to $19 \%$, very low, from 20 to $39 \%$, low, de 40 to $59 \%$ regular, from 60 to $79 \%$, high or positive; and from 80 to $100 \%$, very high or excellent (UABC, 2010). The results of the research for all the data obtained are presented next. Table 1 shows the results for the questions related to the development of generic competences related to learning how to know where the promotion of autonomous work, the search for information in different sources and the acquisition of knowledge can be identified as strengths. The results also reflect the need to encourage activities in which students can apply the understanding of a second language. 
Table 1. Student opinion results on the development of competences related to learning how to know

\begin{tabular}{lccc}
\hline \multicolumn{1}{c}{ Generic competence } & Disagree & Partially agree & Agree \\
\hline Organizing projects & 13.3 & 29.9 & 56.8 \\
Working in an autonomous way & 10.9 & 21.5 & 67.6 \\
Comprehending a second language & 44.4 & 24.8 & 30.8 \\
Searching for information on different sources & 12.4 & 26 & 61.6 \\
Acquiring knowledge of a determined field & 7.2 & 17.6 & 75.2 \\
\hline
\end{tabular}

In Table 2 we present a group of questions corresponding to the development of generic competences related to learning how to do. Among the most solid competencies are the application of previous knowledge in problem solving, decision making, problem-solving and working with quality. On the other hand, the results indicate that the promotion of creative capacity is adequately addressed.

Table 2. Student opinion results on the development of competences related to learning how to do

\begin{tabular}{lccc}
\hline \multicolumn{1}{c}{ Generic competence } & Disagree & Partially agree & Agree \\
\hline Applying previous knowledge in problem solving & 8.5 & 21.8 & 69.7 \\
Creative capacity & 13.9 & 26.6 & 59.5 \\
Decision making & 10.6 & 21.8 & 67.7 \\
Capacity to solve problems & 6.9 & 18.1 & 75.0 \\
Quality work & 10.5 & 18.4 & 71.0 \\
\hline
\end{tabular}

Table 3 informs about the results where we can observe the competences related to learning how to be. There is a high percentage of students who believe that their ability to organize their time is encouraged, while a regular percentage of students report that self-criticism is being built on their daily performance as well as leadership. Oral and written communication represents an opportunity for improvement in the program, since a low percentage of students consider that this competence is adequately promoted in the basic courses.

Table 3. Student opinion results on the development of competences related to learning how to be.

\begin{tabular}{lccc}
\hline \multicolumn{1}{c}{ Generic competence } & Disagree & Partially agree & Agree \\
\hline Capacity of self-criticism of their daily performance & 14.2 & 28.2 & 57.6 \\
Oral and written communication & 28.1 & 32.6 & 39.3 \\
Organizing their time & 11.5 & 27.7 & 60.8 \\
Leadership & 24.0 & 25.0 & 51.0 \\
\hline
\end{tabular}

The results presented in Table 4 refer to the generic competences related to learning how to live together. A regular percentage of students expressed their agreement that the commitment of their profession to society and coexistence is encouraged; while identifying as an opportunity for improvement the promotion of commitment to the preservation of the environment and tolerance.

Table 4. Student opinion results on the development of competences related to learning how to live together.

\begin{tabular}{lccc}
\hline \multicolumn{1}{c}{ Generic competence } & Disagree & Partially agree & Agree \\
\hline Commitment to the environment preservation & 28.1 & 26.2 & 45.7 \\
Commitment of their profession to society & 24.2 & 23.5 & 52.3 \\
Tolerance & 28.2 & 24.2 & 47.6 \\
Coexistence & 19.7 & 27.0 & 53.3 \\
\hline
\end{tabular}

\section{Conclusions}

The study reflect upon the generic competences that students consider are being promoted during their first years in the university and provides a reference for the methodology to identify development of generic skills in engineering students. Students consider that competences related to learning to do are promoted satisfactorily during their first years of training. The records of the study show the need to privilege both technical and practical training as the humanist part of engineering students. Learning how to live together and learning how to be, are two of the four pillars of learning where engineering training program has the biggest improvement opportunity to assure generic competences development: Commitment to the environment preservation, Commitment of their profession to society, Tolerance and Coexistence, and the Comprehending a second 
language, are skills that students consider should be promoted as part of the formative process of the first years. Oral and written communication and Leadership must be developed more effectively to improve skills related the learning to be pillar. Creative ability should be promoted in different ways because of its importance in positively influence the development of science and technology based on knowledge and innovation. Outside of the Institution, this study allows us to identify similarities in the case of UABC and other IES regarding the factors that can strengthen or obstruct a generic skills development on higher education programs, as the fact that not all interpersonal and linguistic abilities have been developed in the same grade as the technical capacities during the professional training. The following recommendations arise based on the contributions made by different people in the University that collaborated in building this project, as well as the results and conclusions of the study. The proposals were generated in four axes related to the four pillars of education. 1) Learning to live together: to establish mechanisms that allow the unification, dissemination, and evaluation of humanistic competences in engineering students; to train the teachers on teaching and learning strategies that promote the development of humanistic competences in engineering students. To establish accompaniment programs for foreign new students where the cultural exchange and respect to diversity are promoted; to implement reading and writing student programs. To provide a bigger assessment to programs in the Engineering Faculty dedicated to promote the commitment to the environment and the community. 2) Learning to be: to review the course of study of subjects in order to establish unified criteria about the generic competences that should be developed in engineering students on the first phase of the training process. 3) Learning to be: To diversify learning experiences where the creative capacity and leadership of the students are promoted. Increase the assessment of permanent programs where student participate in internal and external university research projects. 4) Learning to know: design teaching-learning environments where the use of a second language is required. Lastly, it is concluded that the development of competences in engineering students is the result of the instrumentation of teaching-learning, for which we can identify the need to make following studies in order to identify the teaching strategies and the evaluation of humanistic competences used by teachers in the basic training phase.

\section{References}

Academia de Ingeniería. (2007). Reflexiones sobre el futuro de la ingeniería en México o Ingeniería Profesión Quijotesca. (P. José Salvador Echeverría Villagómez, Ed.) Retrieved form http://www.ai.org.mx/archivos/coloquios/1/Reflexion_sobre_el_Futuro_de_la_Ingenieria/Reflexion\%20sob re\%20el\%20Futuro\%20de\%20la\%20Ingenieria_escrito.pdf

Amieva, R. L. (2001). Elaboración de informes en la enseñanza de la ingeniería. Facultad de Ingeniería. Gabinete de Asesoramiento Pedagógico. Universidad Nacional de Río Cuarto. Retrieved from http://www.ehu.eus/PAT/compe/lanak/ELABORACION_DE_INFORMES_EN_LA_ENSENNANZA_DE_ LA_INGENIERIA_informes_lengua\%20y\%20contenido.pdf

Asociación Nacional de Universidades e Instituciones de Educación Superior. (2006). Consolidación y Avance de la educación superior en México. Temas cruciales de la agenda. México. Asociación de Universidades de Educación Superior.

Bellocchio, M. (2010). Educación basada en competencias y constructivismo: Un enfoque y un modelo para la formación pedagógica del siglo XXI (2a. ed.). México, D. F.: Asociación Nacional de Universidades e Instituciones de Educación Superior/Universidad de Colima/Universidad Autónoma de Ciudad Juárez.

Beneitone, P. (2007). Reflexiones y perspectivas de la educación superior en América Latina. Informe Final (Proyecto Tuning, América Latina 2004-2007). Bilbao and Groningen, 2007. 429p.

Corbetta, P. (2007). Metodología y técnicas de investigación social. Madrid: Mc Graw Hill.

De Asís, F. (2007). Competencias profesionales en la formación profesional. Madrid, España: Editorial Alianza.

Delors, J. (1996). La educación encierra un Tesoro. En Informe a la UNESCO de la Comisión Internacional sobre la educación para el siglo XXI (págs. 95-126). Madrid: Santillana-UNESCO.

Etzkowitz, H., \& Leydesdorff, L. (2000): The dynamics of innovation: from National Systems and 'Mode 2' to a Triple Helix of university-industry-government relations, Research Policy, 29(2), 109-123. https://doi.org/10.1016/S0048-7333(99)00055-4

Fernández L., Gutiérrez J., \& Hilera J. (2010). Trabajo en equipo multinacional en ingeniería informática. Universidad de Alcalá. Retrieved from http://www.cc.Uah.es/jagm/docs/2010/CRUE2010.pdf

Gadotti, M. (2003). Pedagogía de la praxis. São Paulo: Pep Aparicio

Galaz, F., \& Sevilla, J. (2007). La universidad vista por sus estudiantes: el caso de una universidad pública 
estatal, en Araceli Mingo Caballero (coord.), Estudiantes universitarios: cinco acercamientos. México, Universidad Nacional Autónoma de México, Coordinación de Humanidades, Instituto de Investigaciones sobre la Universidad y la Educación, 2007.

Ginés, M. J. (2003). Competencias y empleo de los jóvenes graduados universitarios: Revista de educación. Reflexiones sobre política educativa (330), 157-170. ISSN 0034-8082. Retrieved from https://sede.educacion.gob.es/publiventa/detalle.action? $\operatorname{cod}=11213$

González, R. R., \& Hernández, S. P. (2014). Habilidades lingüísticas de los estudiantes de primer ingreso a las instituciones de educación superior. Revista de la Educación Superior. xliii (3). No.171. (171-174). ISSN: 0185-2760. Recuperado de: http://www.redalyc.org/pdf/604/60432070009.pdf

Gordillo, M. M., \& Osorio, M. C. (2003). Educar para participar en ciencia y tecnología. Un proyecto para la difusión de la cultura científica. Revista Iberoamericana de Educación (32). ISSN: 1022-6508. Retrieved from: http://www.rieoei.org/rie32a08.htm

Guerra, G. J., Guevara, B. Y., López, H. A., \& Rugerio, T. J. (julio-diciembre, 2014). Identificación de las estrategias y motivación hacia la lectura, en estudiantes universitarios mexicanos. CPU-e, Revista de Investigación Educativa, 19. ISSN 254-277. Retrieved from http://www.redalyc.org/pdf/2831/283131303009.pdf

Hernández, R. S., Fernández, C. C., Baptista, P. L., \& Collado, C. F. (2003). Metodología de la Investigación. México: Mc Graw Hill.

Medina, P. A., Casillas L. M. E., \& Zayas O. G. (2012). Identificación y selección de competencias genéricas: Caso Educación Superior Tecnológica en México. REXE. Revista de estudios y experiencias en educación, Agosto-Diciembre, 99-122. Retrieved from http://www.redalyc.org/articulo.oa?id=243125410005.

Oliveros, R. M., Sevilla, G. J., \& Shor, M. (2010). A study in the attitudes and opinions of engineering students from the University of Baja California, Mexico, on Science, Technology, and Society. Bulletin of Science, Technology \& Society, 30(2). 113-118. https://doi.org/10.1177/0270467610361231

Perrenoud, P. (2006). Construir competencias desde la escuela. Ediciones Noreste, J. C. Sáez Editor. Santiago, 2006. Retrieved from http://riic.unam.mx/doc/29PERRENOUD-Philippe-cap2-Programas-escolares-y-competencias.pdf

Rojas, R. (1998). El proceso de la investigación científica en México. México, D.F.: Trillas.

Sáez, R. (2006). La educación intercultural. Revista de Educación, 339, 859-881. Universidad Complutense de Madrid.

Tamayo, S. (1994). El proceso de la investigación Científica. México: Limusa.

Torrez. C. O., \& González. A. C. (2002) Recursos humanos para las empresas multinacionales de alta tecnología en Costa Rica: Análisis de las brechas entre oferta y demanda. San José, C.R.: Jiménez \& Tanzi, CAATEC, 2002 Retrieved from .http://www.caatec.org/CAATEC/publicaciones/crdigital/CR_Digital_2.pdf

Triola, F. M. (2000). Estadística Elemental. México: Addison Wesley Longman, Pearson Educación.

UABC. (2010). Encuesta Anual de Ambiente Organizacional 2010. Mexicali, B.C.: Universidad Autónoma de Baja California.

UABC. (2013). Modelo Educativo de la UABC. Universidad Autónoma de Baja California. Retrieved from http://www.redalyc.org/articulo.oa?id=24312541000.

UABC. (2015). Plan de Desarrollo Institucional. Universidad Autónoma de Baja California. Retrieved from http://www.uabc.mx/planeacion/pdi/2015-2019/PDI-2015-2019.pdf

UNESCO. (2017). UNESCO's Strategy for Technical and Vocational Education and Training (2016-2021) Retrieved from http://www.unevoc.unesco.org/go.php?q=UNESCO+TVET+Strategy+2016-2021\&context=

Vázquez-Alonso, Á., \& Manassero Mas, M. A. (2013). La comprensión de un aspecto de la naturaleza de ciencia y tecnología: Una experiencia innovadora para profesores en formación inicial. Revista Eureka sobre Enseñanza y Divulgación de las Ciencias, 10, 630-648.

https://doi.org/10.25267/Rev_Eureka_ensen_divulg_cienc.2013.v10.iextra.10 


\section{Copyrights}

Copyright for this article is retained by the author(s), with first publication rights granted to the journal.

This is an open-access article distributed under the terms and conditions of the Creative Commons Attribution license (http://creativecommons.org/licenses/by/4.0/). 